\title{
Komposisi Larva Ikan pada Tutupan Padang Lamun di Perairan Prawean Bandengan, Kabupaten Jepara
}

\author{
Sri Redjeki, Riska Novianti Putri, Adi Santoso, Sunaryo, Sri Sedjati
}

\author{
Departemen Ilmu Kelautan, Fakultas Perikanan dan Ilmu Kelautan, Universitas Diponegoro \\ Jl. Prof. Soedarto, SH Tembalang, Semarang, 50275 \\ Email: sriredjekikelautan@gmail.com
}

\begin{abstract}
Abstrak
Larva Ikan (ichtyoplankton) merupakan tahapan awal dari daur hidup ikan yang ditandai dengan perkembangan telur, larva dan juvenil, memiliki tingkat mortalitas tinggi dan peka terhadap perubahan lingkungan, predator, dan kesediaan makanan. Fungsi ekologis padang lamun sebagai daerah asuhan dan tempat berlindung bagi semua jenis organisme laut kecil, salah satunya larva ikan. Kerapatan atau tutupan padang lamun juga sebagai salah satu faktor pendukung melimpahnya organisme dan kekayaan di laut. Tujuan penelitian ini untuk mengetahui kelimpahan dan distribusi larva ikan yang terdapat pada ekosistem padang lamun, serta mengetahui hubungan kelimpahan larva ikan dengan tutupan padang lamun di Perairan Prawean Bandengan, Jepara. Metode penelitian ini adalah metode deskriptif dengan penentuan lokasi sampling menggunakan purposive sampling methode. Lokasi penelitian pada 3 stasiun dengan pembagian kerapatan lamun yang berbeda ( $\mathrm{I}=$ Padat ; II = Sedang ; III = Jarang) dan dilakukan sebanyak 3 kali pengulangan sampling di masing-masing lokasi. Pengambilan sampel larva ikan dilakukan dengan menggunakan larva net $(\mathrm{P}=0,9 \mathrm{~m} ; \mathrm{L}: 0,6 \mathrm{~m})$ dengan ukuran mata jaring $800 \mu \mathrm{m}$. Hasil penelitian ini ditemukan larva ikan sebanyak 5 famili yaitu Nemipteridae, Gerreidae, Gobiidae, Labridae, dan Mullidae. Famili larva ikan yang paling sering ditemukan adalah Nemipteridae. Rata - rata kelimpahan famili larva ikan pada Stasiun I sebesar $0,419 \mathrm{Ind} / \mathrm{m}^{3}$, Stasiun II sebesar $0,205 \mathrm{Ind} / \mathrm{m}^{3}$, dan pada stasiun III sebesar 0,069 $\mathrm{Ind} / \mathrm{m}^{3}$. Nilai rata - rata indeks keanekaragaman termasuk dalam kategori rendah sedang $(0,65-1,37)$, indeks keseragaman larva ikan termasuk dalam kategori rendah-tinggi $(0,33-0,65)$ indeks dominasi larva ikan menunjukkan ada yang mendominasi pada tiga stasiun $(0,28-0,30)$ dan indeks sebaran morisita yang dilakukan menunjukkan bahwa sebaran larva ikan pada tiga stasiun merata.
\end{abstract}

Kata kunci : Komposisi, Larva Ikan, Padang Lamun, Perairan Prawean.

\section{Abstract}

\section{Composition of Fish Larvae In Seagrass Beds In Prawean Waters Bandengan Jepara}

Fish larvae (ichthyoplankton) are the initial stages of the fish's life cycle, starting from the development of eggs, larvae, and juveniles, which have a high mortality rate and are sensitive to environmental changes, predators, and food availability. The ecological function of seagrass beds as nurseries and shelter for all types of small marine organisms, one of which is fish larvae. The density or cover of seagrass beds is also one of the supporting factors for the abundance of organisms and wealth in the sea. The purpose of this study was to determine the abundance and distribution of fish larvae found in the seagrass ecosystems and to determine the relationship of abundance of fish larvae with cover seagrass beds in the waters of Prawean Bandengan, Jepara. This research method is a descriptive method by determining the sampling location using purposive sampling method. The research location was in 3 stations with a different distribution of seagrass density $(I=$ Dense; $I I=$ Medium; $I I I=$ Rare $)$ and carried out 3 times repetition of sampling at each location. A sampling of fish larvae was carried out using larvae net $(P=0,9 \mathrm{~m} ; \mathrm{L}: 0,6 \mathrm{~m})$ with a mesh size of $800 \mu \mathrm{m}$. In total, 5 families of fish larvae were obtained, namely Nemipteridae, Gerreidae, Gobiidae, Labridae, and Mullidae. The most common family of fish larvae was Nemipteridae. The average abundance of fish larvae at Station I was 0,419 Ind/ $\mathrm{m}^{3}$, Station II was $0,205 \mathrm{Ind} / \mathrm{m}^{3}$, and at Station III was 0,069 Ind $/ \mathrm{m}^{3}$. The average diversity index was included in the low category $(0,65-1,37)$, the uniformity index of fish larvae was included in the low-high category $(0,33-0,65)$ the fish larvae dominance index shows that there are dominating at three stations $(0,28-0,30)$ and the distribution index of distribution (morisita) conducted showed that the distribution of fish larvae at three stations was evenly distributed.

Keywords : Composition, Fish Larvae, Seagrass, Prawean Waters 


\section{PENDAHULUAN}

Luas lautan yang lebih besar dibandingkan dengan luas daratan, membuat Indonesia memiliki sektor perikanan yang cukup baik, ikan dan udang serta beberapa hasil bahari lainnya menjadi perhatian besar bagi masyarakat Indonesia. Analisis mengenai larva ikan yang terdapat pada ekosistem padang lamun dapat dikatakan sebagai suatu bentuk tinjauan dari fase awal daur dari kehidupan suatu organisme laut dalam hal tersebut larva ikan (Saraswati et al., 2016).

Komposisi larva ikan di Perairan Prawean Bandengan sebelumnya sudah menjadi fokus penelitian pada tahun 2018. Berdasarkan hasil penelitian Hidayaturrohmah (2018), larva ikan yang didapatkan berjumlah 8 famili yakni, Apogonidae, Blennidae, Engraulidae, Gobiidae, Lutjanidae, Mugillidae, Mullidae dan Nemipteridae. Penelitian yang dilakukan di padang lamun dengan tiga perbedaan tingkat kerapatan. Kerapatan lamun dengan tutupan yang tinggi mendapatkan jumlah larva ikan yang lebih banyak disbanding kerapatan lamun yang sedang maupun jarang.

Larva ikan merupakan bagian dari meroplankton yang berada pada tahap awal kehidupan dari ikan setelah telur menetas (early life history), yang pada tahap berikutnya menjadi ikan pelagis yang berenang bebas di perairan (Amri dan Mutoharoh, 2016). Salah satu habitat yang cocok bagi larva ikan yaitu ekosistem lamun. Padang lamun memiliki fungsi ekologis yakni sebagai daerah asuhan (nursery ground), tempat memijah (spawning ground), tempat mencari makan (feeding ground) dan tempat berlindung bagi semua jenis organisme laut salah satunya organisme laut kecil.
Kerapatan atau tutupan padang lamun juga sebagai salah satu faktor pendukung melimpahnya organisme dan kekayaan di laut (Riniatsih, 2016a). Hubungan antara kelimpahan larva ikan dengan tingkat kerapatan lamun dapat dijadikan informasi pengelolaan sumberdaya. Sehingga diperlukan penelitian mengenai hubungan kerapatan lamun dengan komposisi larva ikan, untuk mengetahui informasi sebaran kelimpahan larva ikan dan pentingnya manfaat lamun bagi kehidupan organisme laut kecil.

Perairan Prawean Bandengan Jepara memiliki ekosistem padang lamun dengan tutupan dan jenis yang cukup beragam (Septiani, 2018). Perairan Prawean Bandengan memiliki aktifitas nelayan tangkap yang dilakukan tidak jauh dari pantai yang merupakan wilayah padang lamun.

\section{MATERI DAN METODE}

Materi penelitian yang digunakan dalam penelitian ini adalah sampel larva ikan pada padang lamun yang berbeda di perairan Prawean Bandengan, Kabupaten Jepara. Unsur utama yang dibutuhkan pada penelitian ini merupakan variasi tutupan padang lamun yang terdapat di perairan Prawean Bandengan sebagai salah satu paramater kelimpahan larva ikan. Waktu pengambilan sampel dilakukan 3 kali secara time series dengan rentan waktu satu bulan dan dilakukan pada 24 Februari, 24 Maret, dan 24 April 2019. Penentuan lokasi sampling dilakukan dengan metode pertimbangan (Purposive Sampling Method).

Perhitungan lamun dilakukan berdasarkan Panduan Monitoring Padang Lamun COREMAPCTI LIPI dengan menentukan titik awal ditemukannya lamun kemudian marking titik awal ditemukannya lamun. Rollmeter kemudian ditarik 100 meter vertikal dari titik awal ditemukannya

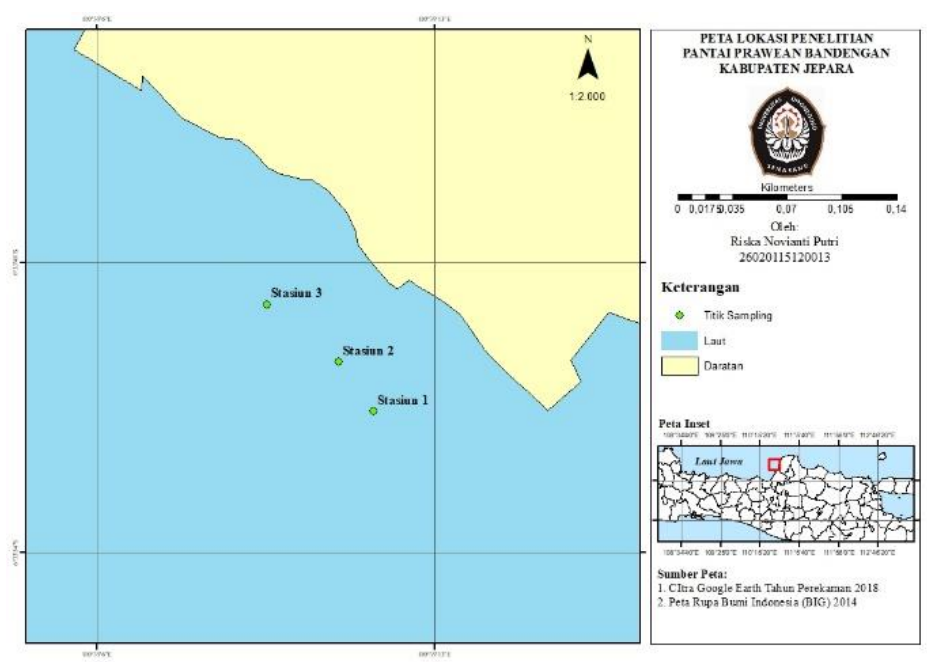

Gambar 1. Lokasi Penelitian 
lamun menuju arah laut, kemudian transek $50 \mathrm{~cm}$ x $50 \mathrm{~cm}$ di letakan pada sisi kanan rollmeter. Pengamatan dilakukan dengan perbedaan jarak 10 meter dari titik awal sampai titik akhir. Perhitungan dilakukan sebanyak 3 line perhitungan untuk menentukan satu stasiun. Pemilihan stasiun dilakukan vertikal mengikuti garis pantai dengan menentukan titik awal ditemukan lamun. Perhitungan kerapatan lamun dan persentase tutupan lamun dari masing-masing jenis spesies (COREMAP-CTI LIPI, 2014)

\section{Pengambilan Sampel Larva Ikan}

Sampel diambil dengan menggunakan larva net dengan mulut jaring persegi panjang $(\mathrm{P}=90$ $\mathrm{cm} ; \mathrm{L}=60 \mathrm{~cm}$ ) dan ukuran mata jaring $800 \mu \mathrm{m}$, seperti pada Gambar 2.

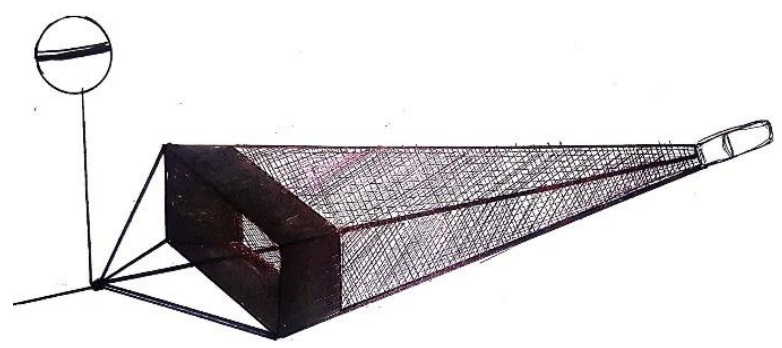

Gambar 2. Larva Net

(Sumber : Sketsa Penulis, 2019)

Pengambilan sampel larva ikan dilakukan saat perairan pasang agar lamun tidak rusak olah larva net. Larva net ditarik sejauh 100 meter secara zig-zag dan pengulangan penarikan dilakukan tiap \pm 15 menit pada tiap pengulangan penarikan dilakukan secara horizontal. Setelah penarikan sampel yang tertampung kemudian dipindahkan pada botol sampel yang kemudian diberikan larutan formalin aldehid $4 \%$ sebanyak $50 \mathrm{ml}$.

\section{Persentase Tutupan Lamun}

Untuk menentukan persentase tutupan lamun suatu lokasi, dengan menghitung terlebih dahulu persentase dalam 1 transek (persamaan 1) yang selanjutnya akan di rata-rata dalam satu stasiun sampling dengan menggunakan rumus COREMAP-CTI LIPI (2014) sebagai berikut:

$$
=\frac{\begin{array}{c}
\text { Persamaan 1 } \\
\text { Jumlah nilai penutupan lamun (4 kotak) }
\end{array}}{24}
$$

$$
\text { Persamaan } 2=\frac{\text { Jumlah nilai penutupan lamun }}{\text { jumlah kuadran seluruh transek }}
$$

\section{Kerapatan Jenis Lamun}

Untuk mengetahui jumlah individu tegakan per satuan luas menurut Odum (1993).

\section{Kelimpahan Larva Ikan}

Banyaknya individu larva ikan yang didapatkan per satuan volume daerah sampling menurut Romimohtarto dan Juwana (1998).

\section{Indeks Keanekaragaman Larva Ikan}

Untuk mengetahui jenis dan jumlah suatu organisme berdasarkan dari jumlah total individu tiap jenisnya. Perhitungan indeks keanekaragaman menurut Odum (1993), dengan kriteria indeks, $\mathrm{H}^{\prime} \leq 1=$ Keanekaragaman rendah; $\quad<\mathrm{H}^{\prime} \leq 3 \quad=$ keanekaragaman sedang; $\mathrm{H}^{\prime}>3$ =keanekaragaman tinggi

\section{Indeks Keseragaman Larva Ikan}

Untuk mengetahui jumlah penyebaran individu yang mendominasi di setiap genus tersebut, perhitungan dengan rumus menurut Odum (1993), dengan Kriteria indeks 0,6-1 = Keseragaman populasi tinggi; $0,4-0,6=$ Keseragaman populasi sedang; $0-0,4=$ Keseragaman populasi rendah

\section{Indeks Dominasi Larva Ikan}

Dominansi dinyatakan dalam indeks dominansi Simpson (Brower dan Zar, 1990) :

\section{Indeks Sebaran Morisita Larva Ikan}

Untuk mengetahui pola penyebaran perifiton pada daun lamun digunakan rumus morosita (Odum, 1993). Dengan kriteria Indeks, $\mathrm{Id}=1,0=$ Penyebaran acak; Id $<1,0=$ Penyebaran merata; $\mathrm{Id}>1,0=$ Penyebaran mengelompok

\section{HASIL DAN PEMBAHASAN}

Persentase lamun yang ditemukan pada lokasi penelitian menyatakan stasiun I sebagai stasiun yang memiliki kerapatan yang padat dengan persentase $69 \%$. Stasiun II sebagai stasiun dengan persentase lamun sedang dengan besar kerapatan $49 \%$, dan stasiun III sebagai lokasi dengan persentase lamun jarang dengan persentase $20 \%$.

Terdapat 6 spesies lamun pada lokasi penelitian yaitu Thalasia hemprichii, Enhalus acoroides, Halodule uninervis, Syringodium isoetifolium, Cymodocea rotundata, dan Cymodocea serrulata.

Kehadiran jenis ikan di perairan Prawean, Bandengan pada Tabel 1 menunjukan bahwa sebanyak 5 famili dari Satu ordo, yakni ordo 
Perciformes. Pengambilan sampel dilakukan pada tiga periode pada tiga tutupan lamun berbeda. Kondisi periaran saat pengambilan sampel dilakukan pada pagi hari saat bulan Februari perairan surut, sangat keruh dan padang lamun tertimbun oleh lumpur. Bulan Maret dan April periran sedang pasang dan arus dalam air sangat kuat. Menurut Subiyanto (2008), migrasi ikan dan kondisi lingkungan sekitar ikan untuk memenuhi kebutuhannya yang dibutuhkan untuk pertumbuhan menjadi salah satu alasan adanya perbedaan jumlah kelimpahan larva ikan.

Tabel 1. Kehadiran Larva Ikan

\begin{tabular}{lcccccccccc}
\hline \multirow{2}{*}{ Famili } & \multicolumn{3}{r}{ Stasiun I } & \multicolumn{3}{c}{ Stasiun II } & \multicolumn{3}{c}{ Stasiun III } \\
\cline { 2 - 11 } & Februari & Maret & April & Februari & Maret & April & Februari & Maret & April \\
\hline Nemipteridae & + & + & + & + & + & + & + & + & + \\
Gerreidae & + & + & + & + & + & + & - & + & + \\
Gobiidae & + & + & + & + & + & + & - & + & - \\
Labridae & - & + & + & - & + & + & - & - & - \\
Mullidae & + & + & + & - & + & + & - & + & - \\
\hline Jumlah & 4 & 5 & 5 & 3 & 5 & 5 & 1 & 4 & 2 \\
\hline
\end{tabular}

Keterangan: $(+)=$ Ada; $(-)=$ Tidak Ada

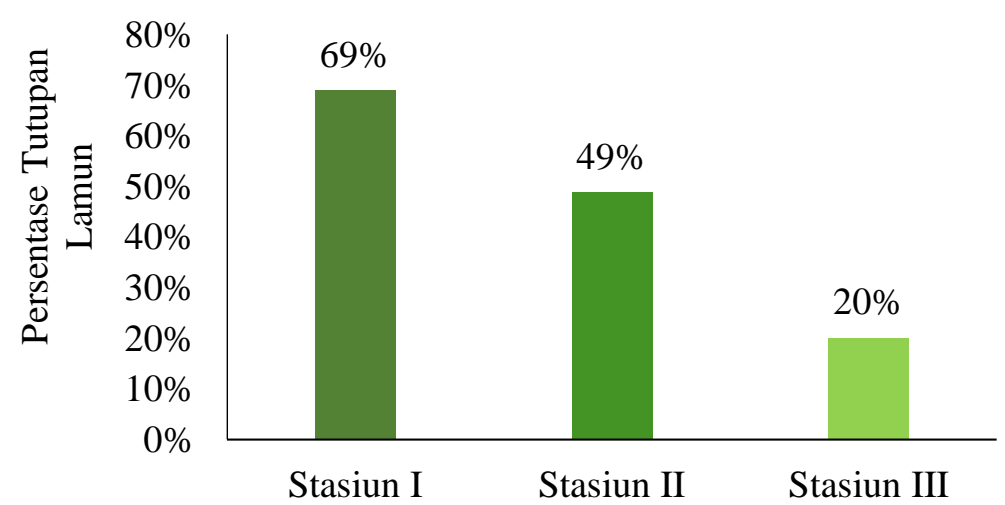

Gambar 3. Persentase Tutupan Padang Lamun

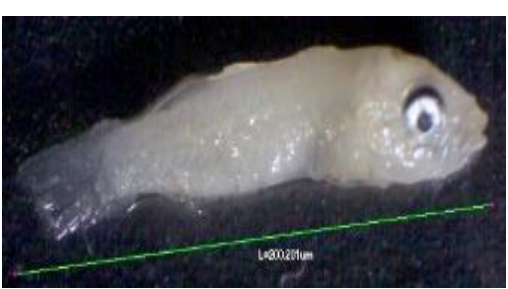

Nemipteridae

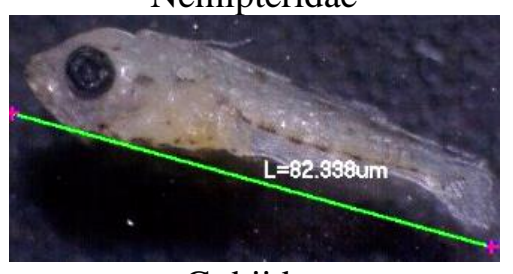

Gobiidae

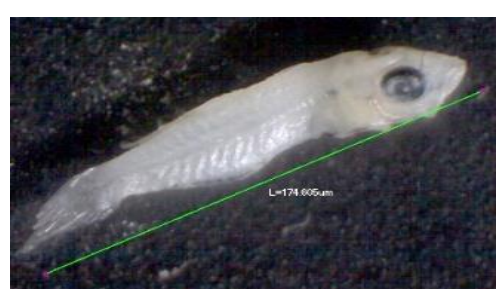

Gerreidae

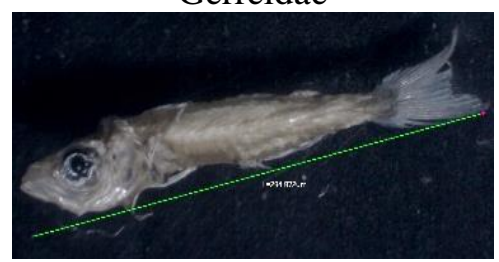

Labridae

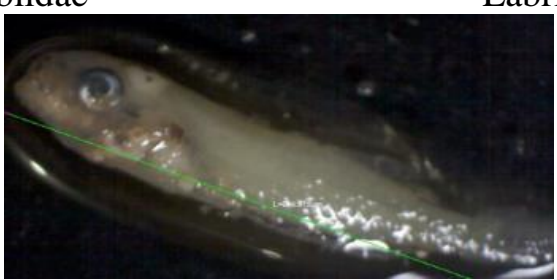

Mullidae

Gambar 4. Famili Larva Ikan yang ditemukan di Perairan Prawean Bandengan, Kabupaten Jepara 
Sebagian besar larva ikan yang ditemukan pada penelitian ini merupakan larva ikan postflexion pada fase ini larva ikan memiliki bagian tubuh dan organ yang terbentuk hampir sempurna. Berbeda pada fase flexion pada fase ini tubuh larva ikan hampir mendekati fase ikan kecil atau juvenil yang memiliki bagian-bagian tubuh seperti ikan dewasa. Pada fase post-flexion larva ikan sudah memiliki sirip yang hampir terbentuk sempurna yang memudahkan ikan untuk berenang atau bergerak bebas di perairan (Gambar 5). Larva ikan pada fase post-flexion akan berenang bebas sampai ke perairan yang lebih dangkal seperti pada daerah terumbu karang, padang lamun, dan mangrove untuk mencari sumber makanan dalam masa berkembang (Hidayaturrohman, 2018).

Famili Nemipteridae merupakan famili larva ikan yang paling banyak ditemukan dengan nilai 26\%. Famili Gerreidae memiliki nilai komposisi sebesar $23 \%$ dan famili Gobiidae sebesar $21 \%$. Famili Mullidae sebesar $18 \%$ dan famili Labridae sebesar $12 \%$. Nilai pada Gambar 5 menunjukan bahwa larva ikan yang mendominasi di perairan Prawean, Bandengan merupakan famili Nemipteridae. Menurut Oktaviyani (2014), Famili Nemipteridae merupakan famili yang tumbuh di perairan dengan substrat pasir atau lumpur dan cenderung hidup air dengan kedalaman cukup tinggi dengan hidup bergerombol.

Famili Gobiidae adalah salah satu ikan yang menggunakan padang lamun sebagai tempat memijah, ketika dewasa sebagian larvanya akan tetap tinggal dan sebagian lain akan berpindah ke ekosistem mangrove, terumbu karang, maupun lautan lepas (Redjeki, 2013). Famili Labridae merupakan famili ikan yang biasa ditemukan pada daerah ekosistem karang namun famili memiliki fenomena migrasi pada siang hari untuk mencari simber makanan lain (Mujiyanto, 2015).

Rata - rata kelimpahan Famili larva ikan yang paling melimpah di perairan Prawean Bandengan, Jepara dalam jangka waktu tiga bulan dapat dilihat pada Gambar 6. stasiun I dengan kategori tutupan lamun padat memiliki rata - rata kelimpahan larva sebesar $0,419 \mathrm{Ind} / \mathrm{m}^{3}$. Stasiun II dengan ketegori tutupan lamun kategori sedang memiliki rata - rata kelimpahan sebesar 0,205 $\mathrm{Ind} / \mathrm{m}^{3}$. Rata - rata kelimpahan pada stasiun III dengan kategori tutupan lamun jarang sebesar $0,069 \mathrm{ind} / \mathrm{m}^{3}$.

Menurut Saraswati (2016), terdapat 6 faktor yang mempengaruhi distribusi dan kelimpahan larva ikan yakni (1) waktu dan lokasi pemijahan ikan dewasa, (2) kondisi hidrografis seperti arus, pasang surut, dan kondisi kualitas perairan, (3) topografi lokasi pengambilan sampel, (4) distribusi vertical larva ikan, (5) daya renang horizontal larva ikan dan (6) perilaku larva ikan. Hal ini diperkuat oleh Arshad (2013), bahwa arus pasang surut merupakan salah satu faktor utama yang mengendalikan spesies, distribusi dan kelimpahan orgnanisme laut salah satunya larva ikan.

Ikan tangkapan nelayan pada perairan Prawean Bandengan didominasi oleh ikan Kurisi (Nemipterus celebicus) dan ikan Kapasan (Gerres oyena). Selain ikan kurisi dan kapasan, nelayan setempat juga mendapatkan ikan tunul (Sphyraenidae sp.), ikan pendek, ikan kembung (Scombridae sp.), ikan kakap (Lutjanus sp.), ikan badong (Carangidae sp.) Ikan dewasa lain yang tertangkap pada perairan tersebut dapat diakibatkan oleh arus perairan yang menyebabkan beberapa jenis ikan lain akan berenang menuju perairan Prawean Bandengan.

Tingginya keanekaragaman jenis tangkapan ikan menunjukkan bahwa perairan Prawean merupakan perairan dengan ekosistem yang baik bagi tumbuh kembang ikan. Banyaknya ikan dewasa famili Nemipteriade karena famili Nemipteridae cenderung merupakan jenis ikan yang tidak melakukan migrasi sehingga cenderung merupakan jenis ikan yang selalu menetap disuatu habitat (Oktaviyani, 2014).

\section{Hubungan Kelimpahan Larva Ikan dengan Kerapatan Lamun}

Hubungan antara kelimpahan larva ikan dengan kerapatan lamun di perairan Prawean, Bandengan dengan melakukan Uji Korelasi yang menghasilkan liniar yang mnunjukan angka positif pada Gambar 7. hasil analisis uji korelasi hubungan kelimpahan larva ikan dengan kerapatan lamun menunjukan nilai $\mathrm{R}$ Square didapatakan sebesar 0,626 dan nilai $\mathrm{R}$ sebesar 0,712. Menurut Riniatsih (2016b), kondisi perairan bandengan memiliki persentase tutupan padang lamun yang relative tinggi yang cocok dijadikan tempat berlindung dan mencari makan.

Adanya kondisi fisika, kimia, dan biologi perairan juga berpengaruh besar terhadap kondisi padang lamun (Hidayaturrohman, 2018). Kondisi curah hujan yang berbeda pada tiap pengamnilan sampel membuat nilai pengukuran kualitas perairan memiliki perbedaan. Perbedaan hasil pengukuran kualitas air dan baku mutu dapat diakibatkan oleh berbagai faktor, salah satunya adalah kegiatan pariwisata dan kegiatan nelayan yang terdapat di sekitar perairan Prawean 


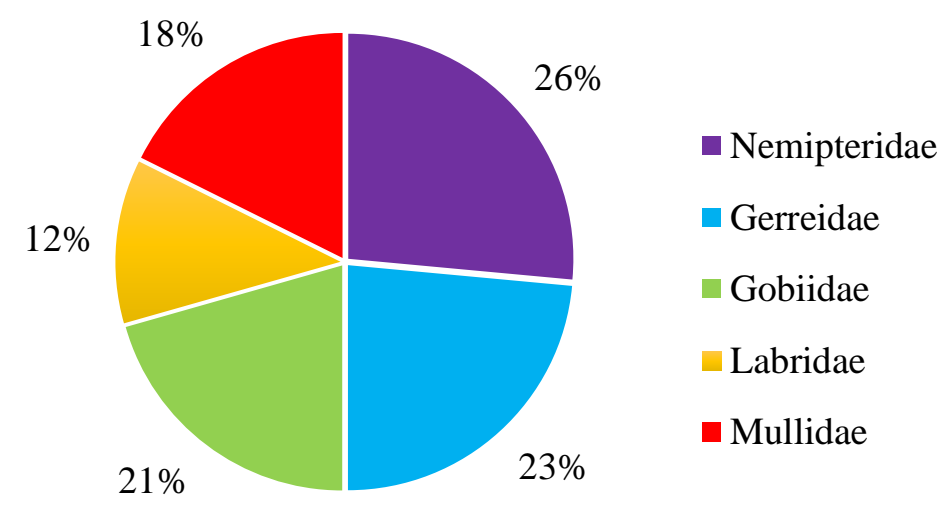

Gambar 5. Komposisi Larva Ikan

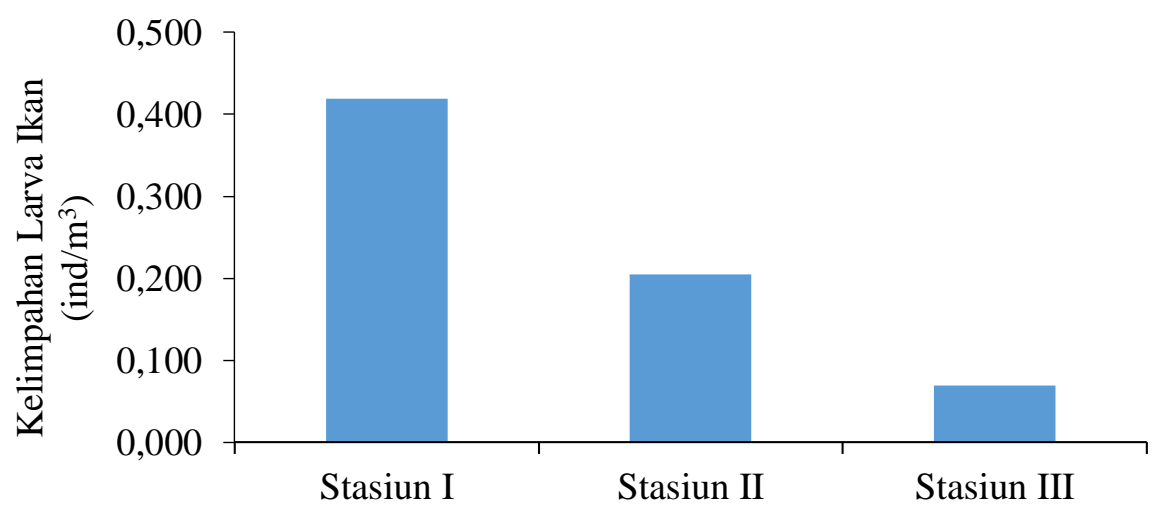

Gambar 6. Kelimpahan Larva Ikan

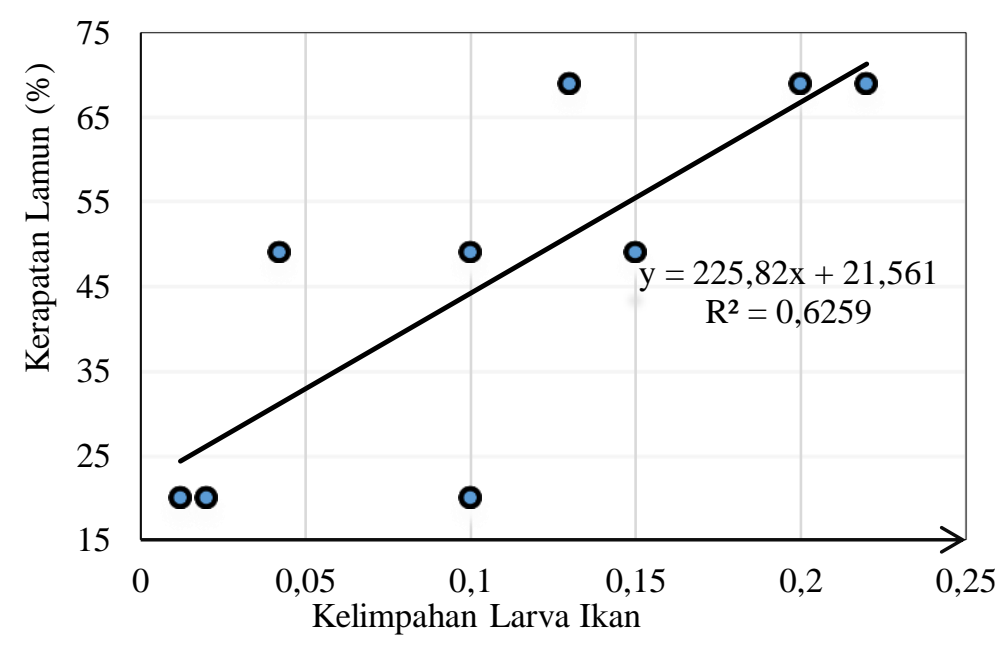

Gambar 7. Hubungan Kelimpahan Larva Ikan dengan Persentase Tutupan Lamun

Bandengan. Menurut Prita et al. (2014), sumber pencemaran yang potensial di perairan adalah aktivitas manusia, kegiatan rumah tangga, kegiatan pariwisata, dan kegiatan transportasi. Menurut Riniatsih (2016b), faktor lingkungan dapat mempengaruhi kelimpahan dan keseragaman spesies biota di suatu ekosistem.

\section{KESIMPULAN}

Berdasarkan dari penelitian tersebut dapat diambil kesimpulan sebagai berikut : Larva ikan yang ditemukan yakni Nemipteridae, Gerreidae, Gobiidae, Labridae, dan Mullidae. Rata - rata kelimpahan Famili larva ikan pada Stasiun I sebesar 0,419 Ind $/ \mathrm{m}^{3}$, Stasiun II sebesar 0,205 
ind $/ \mathrm{m}^{3}$, dan pada stasiun III sebesar $0,069 \mathrm{ind} / \mathrm{m}^{3}$. Nilai rata - rata indeks keanekaragaman termasuk dalam kategori rendah-sedang $(0,65-1,37)$; indeks keseragamannya termasuk dalam kategori rendahtinggi $(0,33-0,65)$; indeks dominasi menunjukan tidak ada yang mendominasi $(0,28-0,30)$ dan indeks distribusi menunjukan bahwa sebaran larva ikan pada tiga stasiun merata. Terdapat hubungan yang kuat antara kerapatan lamun dengan kelimpahan larva ikan. Penelitian tersebut diharapkan dapat memberikan informasi lanjutan tentang kondisi kelimpahan larva ikan diperairan tersebut dan sebagai informasi pentingnya lamun bagi kehidupan biota laut.

\section{DAFTAR PUSTAKA}

Amri, K. \& Mutoharoh, A. 2016. Sebaran Larva Ikan dan Kaitannya Dengan Kondisi Oseanografi Laut Sulawesi. Jurnal Penelitian Perikanan Indonesia, 21(2): 103-114.

Arshad, A. 2013. Diet Composition In Larval Fishes of The Family Terapontidae (Actinopterygii: Perciformes) In The Seagrass-Bed Of Johor Strait, Malaysia. Asian Journal of Animal and Veterinary Advances, 8(2): 325-332

Brower, E.J. \& Zar, J.H. 1977. Field and Laboratory Methods for General Ecology. Wm. C. Brown Company Publisher. Dubuque, lowa. $194 \mathrm{hlm}$.

COREMAP-CTI LIPI. 2014. Panduan Monitoring Padang Lamun. PT. Sarana Komunikasi Utama, Jakarta. $45 \mathrm{hlm}$.

COREMAP-CTI LIPI. 2017. Status Padang Lamun Indonesia 2017. Pusat Penelitian Oseanografi - LIPI, Jakarta. $26 \mathrm{hlm}$.

Hidayaturrohman, F. 2018. Kelimpahan Larva Ikan Berdasarkan Fase Bulan di Padang Lamun Pantai Prawean Jepara. Journal of Maquares. 7(4):431-439

Mujiyanto, M. 2015. Sebaran Jenis-jenis Ikan Famili Labridae di Taman Nasional Kepulauan Karimunjawa Jawa Tengah.
Prosiding Forum Nasional Pemulihan dan Koservasi Sumberdaya Ikan, KSI-PI 52.

Odum, E.P. 1993. Dasar-dasar Ekologi. Gramedia, Jakarta. 267 hlm.

Oktaviyani, S. 2014. Karakteristik Morofologi dan Aspek Biologi Ikan Kurisi, Nemipterus japonicus. Pusat Penelitian Oseanografi-LIPI, Jakarta, 39(4):29-34.

Prita, A.W., Riniatsih, I. \& Ario, R. 2014. Struktur Komunitas Fitoplankton pada Ekosistem Padang Lamun Di Perairan Pantai Prawean Bandengan, Jepara. Journal of Marine Research, 3(3):380-387.

Redjeki, Sri. 2013. Komposisi dan Kelimpahan Ikan di Ekosistem Mangrove di Kedungmalang, Jepara. Jurnal Ilmu Kelautan, 18(1):54-60.

Riniatsih, I. 2016a. Distribusi Jenis Lamun Dihubungkan dengan Sebaran Nutrien Perairan di Padang Lamun Teluk Awur Jepara. Jurnal Kelautan Tropis, 19(2):101107.

Riniatsih, I. 2016b. Struktur Komunitas Larva Ikan pada Ekosistem Padang Lamun Di Perairan Jepara. Jurnal Kelautan Tropis, 19(1):21-28.

Romimohtarto, K. \& Juwana, S., 1998. Plankton Larva Hewan Laut. Pusat Penelitian dan Pengembangan Oseanologi. Jakarta. 105hlm.

Saraswati., Solichin, A., Hartoko, A. \& Suharti, A.R. 2017. Hubungan Kerapatan Lamun dengan Kelimpahan Larva Ikan di Pulau Pramuka, Kepulauan Seribu Jakarta. Diponegoro Journal of Maquares, 5(3):11153.

Septiani, E.F. 2018. Pemetaan Karbon Di Padang Lamun Pantai Prawean Bandengan Jepara. Majalah Ilmiah Globe, 20(2):117-124.

Subiyanto, Ruswahyuni, \& Cahyono, D.G. 2008. Komposisi dan Distribusi Larva Ikan Pelagis Di Estuaria Pelawangan Timur, Segara Anakan, Cilacap. Jurnal Saintek Perikanan, 4(1):62-68. 